JOURNAL

OF TOURISM

AND ECONOMIC
Journal of Tourism and Economic Vol.4, No.1, 2021, Page 28-37

ISSN: 2622-4631 (print), ISSN: 2622-495X (online)

Email:jurnalapi@gmail.com

Website: http://jurnal.stieparapi.ac.id/index.php/JTEC

DOI: https://doi.org/10.36594/jtec.v4i1.107

\title{
THE PERCEPTION OF TOUR GUIDE TRAINING: AN INSIGHT FROM THE BORDERAREA OF INDONESIA
}

\author{
Ira Mutiaraningrum \\ Tourism Business Management, State Polytechnic of Sambas, Indonesia \\ ira.mutiaraningrum@,gmail.com \\ Hikmah Trisnawati \\ Tourism Business Management, State Polytechnic of Sambas, Indonesia \\ hikmah.trisnawati@gmail.com \\ Tita Rosalina \\ Tourism Business Management, State Polytechnic of Sambas, Indonesia \\ syafiq605@yahoo.com
}

\begin{abstract}
Temajuk village is one of the leading tourist attractions in West Kalimantan. It bridges Indonesia and Malaysia. With its rich culture and breathtaking scenery, Temajuk village is indispensably for promoting tourism in West Kalimantan. This study examines the participants' perception of the tour guide training held in Temajuk Village. The training involved English lessons since the international tourists also visited Temajuk village through Telok Melano, Indonesia. Employing qualitative study, using interview and observation, this study establishes the reasons and expectations underpinning the respondents in joining the training. The responses are presented into the perceived benefits from the participants' point of view, tour guide training and English language learning, and participants' expectation. It is advised that this kind of training, especially in the border area can be held to since it is fruitful and prominent.
\end{abstract}

Keywords: tour guide training, Temajuk village, perception, the border area 


\begin{abstract}
ABSTRAK
Desa Temajuk merupakan salah satu destinasi wisata unggulan di Kalimantan Barat. Desa ini menjembatani Indonesia dan Malaysia lewat jalur darat. Dengan kekayaan budaya dan pemandangan alam yang mempesona, promosi pariwisata Desa Temajuk sangat dibutuhkan untuk kemajuan pariwisata Kalimantan Barat. Penelitian ini mengkaji persepsi peserta terhadap pelatihan pramuwisata yang diadakan di Desa Temajuk oleh Politeknik Negeri Sambas. Pelatihan tersebut juga mengajarkan komunikasi dasar dalam bahasa Inggris karena turis internasional juga turut mengunjungi desa Temajuk melalui Telok Melano, Indonesia. Melalui studi kualitatif, dengan wawancara dan observasi, penelitian ini mengungkap alasan dan ekspektasi yang mendasari responden untuk mengikuti pelatihan. Tanggapan tersebut disajikan dalam bentuk manfaat yang dirasakan dari sudut pandang peserta, tanggapan tentang pelatihan pramuwisata, dan pengalaman pembelajaran bahasa Inggris, serta harapan peserta untuk kemajuan pramuwisata di Desa Temajuk kedepannya. Diharapkan, pelatihan pramuwisata, khususnya di daerah perbatasan bisa diadakan secara rutin.
\end{abstract}

Kata Kunci: Pelatihan pramuwisata, Desa Temajuk, persepsi, daeraah perbatasan 


\section{INTRODUCTION}

Of several passages connecting Indonesia and Malaysia, Temajuk Village in Paloh District, Sambas Regency, West Kalimantan, Indonesia is one of the crossborder to Telok Melano Sarawak Village, Malaysia. Thus, the tourism sector in the border area becomes a big potential for Temajuk Village, not only due to its strategic location which is directly adjacent to neighboring countries but also because of the natural scenery of its beaches and hills. Temajuk Village became famous especially after the news about Dusun Camar Bulan in Temajuk Village which was threatened to be taken over by Malaysia. Since then, Temajuk Village has increasingly attracted tourists, businessmen, and academics to visit this area.

Based on the data described by Bariyah, Fariastuti, and Kurniasih (2019), the location of Temajuk Village is $200 \mathrm{~km}$ from Singkkawang and can be reached in approximately 6 hours of travel by car. It is considered easy to access because the road that connects the village via Sungai Bening is pretty good; a bit bumpy but it is so much better than the old road via Paloh. Bariyah et al. (2019) further describe the main occupation of residents in Temajuk Village who are pepper and rubber plantation farmers as well as fishermen who sell their fish in Indonesia or Malaysia depending on more competitive prices. Despite the rich natural resources blessing Temajuk Village, many of its people went to Malaysia to seek better employment. Some of the residents of Temajuk Village work in Malaysia as laborers illegally (Bariyah et al., 2019). This is also a threat to the village that many of its potential human resources leave the village.

The development of natural and human resources in border areas is very important to study. To overcome social and economic disparities and conflicts, development in coastal border areas, through empowerment programs, is an important priority (Sugito, Sabiq, Faozanudin \& Kuncoro, 2018). This needs serious concern for the sake of Temajuk village's people's wellbeing and prosperity. Sugito et al. (2018) also added that urbanization, unemployment, poverty, and the shortage of village human resources due to residents working as laborers abroad are threats to village development. Thus, the improvement of human resources is indispensable for better area development. Sugito et al. also emphasized that accelerating the equality and welfare of rural communities is one of the efforts to maintain sovereignty, a sense of nationalism, and justice. Hence, capacity development is imperative for people in Temajuk village.

A previous study conducted by Weiler and Ham in 2012 described a model for sustainable capacity building in developing countries of Panama, Argentina, and Ecuador in terms of longterm tour guide training. The paper deals with the role of guide training as a sustainable development tool. According to Isdarmanto, Dwiatmadja, Sunarto, and Abdi (2020), Indonesia's tourism development exposes a tremendous significant increase in the regions as well as society's economic development. Thus, Isdarmanto et al. (2020) proffer further that the participation of the local community is paramount in terms of their contribution to policymaking for regional tourism development. Thus, quality human resource is indispensable. Globalization and industry 4.0 require innovation and improvement of the quality human resources. Considering that Temajuk Village in Sambas district is a border area, it is common for countries like Malaysia, Brunei Darussalam, Singapore, or even China to visit Temajuk village. Residents of rural areas generally have low levels of education and do not respond to current developments and technology. In connection with these problems, it is necessary to empower the people of Temajuk Village through tourism. 
According to the Law of The Republic of Indonesia Number 10 of 2009 Concerning Tourism Article 1 (3), Tourism shall mean many types of tour activities and supported by many facilities and services provided by the community, businessmen, Government, and Regional Government. Article 1 (7) Tourism business shall mean the business providing the goods and/or services for the fulfillment of the tourists' need and tourism administration. In Article 4, it is described that Tourism Affairs shall be intended to (1) increase the economic growth, (2); improve the people's welfare; (3) eradicate poverty; (4) overcome unemployment; (5) preserve the nature, environment, and resources; (6) promote the culture; (7) raise the nation's image; (8) foster a sense of patriotic; (9) strengthen the nation identity and unity; and (10) strengthen inter-nation friendship.

In the Law of The Republic of Indonesia Number 10 of 2009 Concerning Tourism Article 14 that Tourism business shall cover guide service. Thus, State Polytechnic of Sambas, in Sambas Regency, West Kalimantan, located five hours from Temajuk Village, hold a tour guide training program for the people in Temajuk Village. Through this program, participants are expected to have a Tour

Guide Package along with communication skills (English for Communication) so that they can become a tour guide field. Therefore, we took the theme of PKM which is in line with the Tourism Business Management study program, namely the theme "Human Development and National Competitiveness" through training in making Tour Guide Packages and training in communication in English in the field of Tour Guide for border communities in Temajuk village, Sambas Regency, West Kalimantan, Indonesia.

This paper attempts to describe the perceptions of the participants who joined the tour guide training. Since this kind of training is the first time in Temajuk
Village, there is importance of seeking for the perception of the participants who joined this training. By reckoning the results of this study, future steps for society empowerment can be foreseen. This study provides novelty in which society empowerment through Tour guide training has been under-researched, specifically in the border area of Indonesia. There has been very limited study concerning the perception of people in the border areas on tour guide training. Thus, the results of this study may shed a light in terms of the perception of people in the border areas toward tour guide training.

\section{LITERATURE REVIEW}

\section{Perception}

According to oxford learners dictionaries online, perception is an idea, a belief, or an image you have as a result of how you see or understand something, the way you notice things, especially with the senses, and the ability to understand the true nature of something. Qiong (2017) divides perception into three stages namely selection, organization, and interpretation. In the selection stage, one converts the environment stimuli into a meaningful experience. However, since converting all stimuli is overloading, one selects the meaningful one for the perception. In the organization stage, the stimuli selected were organized in some way by finding certain meaningful patterns accomplished by putting things into categories. Lastly, the interpretation stage deals with the process of attaching and assigning meaning to the selected stimuli. Thus, perception is the emerging themes that are regarded as important. Thus, the exploration of one's perception may be broadened by the examination of participant perception indicators of assessment for diagnosis comprising knowledge, experience, and confidence of the participants (Berger, Kerner, \& Lee, 1999). 


\section{Human Development and National Competitiveness}

Human resource development in Indonesia is an evergreen topic to be discussed. Blessed with rich natural resources, the optimization of human resources enables welfare distribution. Indonesia has been struggling with its economic development. Adam and Negara (2015) argue that despite its impressive economic growth, Indonesia still lags behind the quality of its human capital behind other countries with a similar income level. They continue that Indonesia needs to improve its current skill-training and education system in order to benefit from its demographic bonus Thus, the quality of human resources is prominent. Well educated and trained people, knowledge and skills as well as technological and network readiness in an innovation-rich world are required to improve economic competitiveness (Lonska \& Boronenko, 2015). It is in line with Adam and Negara (2015) who proffer this low quality of human capital relates to the lack of clarity and focus strategies to develop the education system. Fathin, Perdana, Kartikasari, and Sulistyastuti (2014) in their study present a quite significant increase in the number of foreign workers in Indonesia. This shows the urgency of the need for domestic professional workers in Indonesia. The countries with high competitiveness will derive great benefits (Fathin et al., 2014).

\section{Tour guiding}

Law of The Republic of Indonesia Number 10 of 2009 Concerning Tourism Article 14 Paragraph (1) Item k that reads: by "guide service business" shall mean the business providing and/or coordinating the tour guide personnel to fulfill the tourists' needs and/or travel agents' need. According to Yoeti (2010), a tour guide is the person in charge of providing guidance, information, and references about tourist attractions or destinations. Tour guide's ability in understanding the needs of visitors is needed to make visitors feel comfortable (Nurinsani1, Aini, \& Suardi. 2020). Thus, a better skill-train and education system will support the country's effort to reduce youth unemployment as well as poverty (Adam \& Negara, 2015). In the end, it has to be mitigated to anticipate the incoming flow of foreign professional workers that potentially occupy the strategic positions in Indonesia (Fathin et al., 2014). To make a tourism destination is superior to other destinations, promotion is not enough; service plays an important role in visitor satisfaction (Deni \& Winarni, 2017). One of which is the service of a professional tour guide. Deni and Winarni (2017) added that to be a professional tour guide, it is necessary to have experience, technical and theoretical competence.

\section{METHODOLOGY}

This study employs a qualitative method. The instrument used in this study was an interview. The interview was in the form of a semi-structured interview. There were eight participants who were willing to be interviewed. The data was enriched by the observation noticed by the authors during the data collection.

There were five leading questions for the interview. These open-ended questions were constructed as the main opening chance for and further questions in the actual data collection. The indicators selected for the interview questions inspired by Berger, Kerner, and Lee's (1999) participant perception indicators of assessment for diagnosis comprising knowledge, experience, and confidence. The questions were made suitable to the context being discussed in this study.

The interview results were analyzed using Miles and Huberman's (1994) qualitative data analysis namely data reduction, data display, and conclusion drawing/verification. Data reduction deals with the selection of the most basic important points of the 
interview. The essential points were highlighted and marked, especially those with repeated or frequently mentioned themes. The irrelevant topics were discarded to ease the analysis. Data display deals with the organization and assembly of the important themes to ease the conclusion drawing. The last one, conclusion drawing is the patterns analyzed from the themes.

\section{RESULTS AND DISCUSSION}

The results and discussion of this study comprise the delineation of perceived benefits from the participants' point of view, tour guide training and English language learning, and participants' expectation. To obtain a reliable answer. There were five leading questions given to the participants: (1) their feeling of having the tour guide training, (2) the benefits they obtain from the training, (3) the new knowledge they get, (4) difficulties they encounter during the training, and (5) their plan/ hope/ expectation. The demographic profile of respondents is depicted in Table 1.

Table 1. Demographic Profile of Respondents

\begin{tabular}{|c|c|c|c|c|}
\hline No & Code & Age & $\begin{array}{l}\text { Education } \\
\text { Level }\end{array}$ & $\begin{array}{l}\text { Occupati } \\
\text { on }\end{array}$ \\
\hline 1 & R1 & 26 & $\begin{array}{l}\text { Senior High } \\
\text { School (SMA) }\end{array}$ & Farmer \\
\hline 2 & R2 & 20 & $\begin{array}{l}\text { Senior High } \\
\text { School (SMA) }\end{array}$ & $\begin{array}{l}\text { Universit } \\
\text { y Student }\end{array}$ \\
\hline 3 & R3 & 25 & Diploma & Farmer \\
\hline 4 & R4 & 29 & Master Degree & Officer \\
\hline 5 & R5 & 37 & $\begin{array}{l}\text { Senior High } \\
\text { School (SMA) }\end{array}$ & Farmer \\
\hline 6 & R6 & 16 & $\begin{array}{l}\text { Junior High } \\
\text { School (SMP) }\end{array}$ & Student \\
\hline 7 & R7 & 35 & $\begin{array}{l}\text { Senior High } \\
\text { School (SMA) }\end{array}$ & $\begin{array}{l}\text { Entrepren } \\
\text { eur }\end{array}$ \\
\hline 8 & R8 & 34 & $\begin{array}{l}\text { Senior High } \\
\text { School (SMA) }\end{array}$ & Farmer \\
\hline
\end{tabular}

Source: researchers, 2020

Table 1 shows heterogenic data showing that the participants of this study were different in age, occupations, and level of education. Thus, to ensure that all participants find their study at ease, they were given a pocketbook during the training. The pocketbook given to the participants covers the material such as the definition of tour guide, personal presentation, grooming, basic ethics, attitudes, Indonesia's tour guide ethic code, how to lead a tour, documents to bring for tour guiding, the information needed for a successful tour, and handling the unexpected situation. The English lesson given were greetings, offering help, showing things, swooning direction, farewell as well as possible questions from the tourists as well as how to answer them.

From the data analysis, emerging themes of the findings are presented in the following elaboration.

\section{Perceived Benefits from the Participants' Point of View}

All responses that emerged were positive ones. Motivation as a person's main incentive to perform a particular action (Oletić \& Ilić, 2014) is prominent in driving someone to conduct an act. Thus, the motivation reflected from the participants' answers is the sign that the training is desired and needed. A respondent expressed his joy in being involved in the training.

"I got lost of knowledge it was fun, it felt like I have more confidence. Hopefully I can take my family to join this tour guide training." (R1) "The training is the first time. We thank the State Polytechnic of Sambas for making this happen." (R4)

One respondent spelled out his thought regarding the merits of acquiring more knowledge from the training as follows.

"I think this training makes us think more about our village. It increases our enthusiasm. It shows us the importance of knowledge to elevate the prestige of our village, thus, this 
will help increase community income." (R6)

The training is expected to improve the participants' knowledge which in turn, can improve the income of the people in the Temajuk village. The tourism sector has a big contribution to the growth driving of downstream industry (Wijaya, Arcana, \& Sudarmawan, 2019). This is in line with Weiler and Ham (2002) that the training of local guides open the employment opportunities in developing countries that interpretive guide help obtain economic sustainability.

The lecturers from State Polytechnic of Sambas played a significant role in assisting the community to grow and learn. It was revealed that the presence of experts presenting or giving the workshop to the villagers is needed.

"We have a lack of knowledge to promote the village. It is necessary to have experts who can help promote our village." (R7)

One of the expectations deals with follow-up activity. For example, in the workshop for making the handicraft, it is expected that the workshop does not end in the making process. Rather, the participants demand marketing strategy training.

"We need more assistance for the woman to make handicrafts, not only telling them how to make crafts but also how to market and promote the products." (R3)

Thus, such training is prominent, especially for low-educated people. Quality is the key service success (Pirastyo, Putra, \& Kristiutami, 2020). By exploring what the community is capable of, it can lead them to express adequately their skills and competencies.

\section{Tour Guiding}

English dominates business all over the world. Spoken by over a quarter of the world's population (Murtisari \& Mali, 2018), the importance of learning English is obvious. The tour guide training held by State Polytechnic of Sambas added an English lesson as part of its presentation focusing on English for Tour Guide. Many high school students were enthusiastic about joining the training.

"Young people are more enthusiastic about learning about tourism and also learning English." (R2)

Respondent recognized the English lesson in the training. They acknowledge the training contributing to their English enhancement.

"I got many benefits from this tour guide training such as the knowledge on how to be a good tour guide and English conversation." (R4)

With the inevitable use of English, more respondents uttered their willingness of continuing the same training in the future.

"I want to participate in other activities, next year. I hope there are more students who can assist us, speak English with us." (R2)

"I need more training because I got difficulty in expressing especially those in English, I hope that this activity can be conducted regularly, especially English training." (R5)

The transcripts imply the motivation of the respondents to join follow-up training. As motivation plays a critical role, and it is one that plays a critical role in foreign language acquisition, motivation pushes someone to achieve success (Thohir, 2017). As 
opposed to the anxiety of English that seems to be gravely shared by the Indonesian government till the curriculum was made reducing the English lesson (Murtisari \& Mali, 2018), the people in

Apart from being trained to make a Tour Guide Package and being taught English for Communication for guiding tours along with making travel plans (itineraries), border communities will also be introduced to guiding tour activities. The goal is that people know both the theory and practice of guiding tours. With this training, border communities are expected to know and understand the procedures for becoming a tour guide. It is hoped that the potential for employment in the field of tour guides which has been less productive can be developed to be more efficient and competitive for the community with respect to the local culture. Pertiwi and Sulistyawati (2020) highlight the importance of maintaining a local touch through local experiences. There are many opportunities for work and for a better future with having better English skills. Challenges and opportunities must be interpreted as a medium for competitive advantage for the development of regional tourism which strengthens local identity and the recognition of citizen, build community, as well as activate the forces of social capital (Isdarmanto et al., 2020).

\section{Participants' Expectation}

The participants reflect on the tour guide training they participated in. There was no exact clear-cut of categorizing the respondents' perception and expectation since they might be interrelated but somehow the transcripts provided as follows represent the expectations from the respondents for the future programs. The respondents interviewed stated that there was no problem they encountered during the training.
"There was no barrier during the training; I could receive the lesson well." (R1)

This shows that the participants can overcome their shortcoming if any. Furthermore, the more planned, structured, training is preferred. This is to ensure that the objectives of the training can be attained.

"We need direct practice, with a module, and longer time to be a tour guide." (R6)

"I hope the training doesn't end here and will be continued next year or the next few months in the form of regular classes." (R3)

The participants took this training seriously. They came up with very positive feedbacks toward the training. It was shown by their commitment to showing what they got to be the real prove to benefit Temajuk village.

"We hope that those who have participated in the training can prove that this short training can provide benefits for our village, even for Indonesia." (R1)

Surprisingly, not only limited to the training, one respondent put so much hope to the lecturers who came to Temajuk village that the lecturer can deliver their aspiration to the government.

"We demand students or lecturers to $\log$ our aspirations to the government for better facilities." (R8)

All in all, it can be surmised that the tour guide training is desired and fruitful for the participants in Temajuk village. By having the training, it is possible for Temajuk village to have more local guides in the future to be the source of income. Entrepreneurial action by 
creating a new job opportunity to actualize the new business potential for all opportunities is needed (Isdarmanto et al., 2020).

"Sustainable tourism if planned and well managed can directly and

positively contribute to the achievement of Indonesia's Millennium Development Goals, including poverty reduction, rural development, cultural and community preservation, gender equality, environmental protection, climate change mitigation and demonstrate beneficial impacts on change mitigation climate" (Wijaya et al., 2019: 233).

The training for the local guide itself can be in form of foreign languages, tourism objects knowledge, and tourism service quality training (Wisnawa, Wijayanti, \& Jokosaharjo, 2019). However, the success of the programs depends largely on the support from all parties, especially the strategic plan on tourism. It is necessary to have a concrete guideline for various ministries involved in tourism development (Wijaya et al., 2019). With the appropriate sequenced training, support from all parties, and adequate time allotment, that suits the people's need, the outcome will benefit all community strata, not limited to the privileged ones.

\section{CONCLUSION}

This study examines the participants' perception toward tour guide training in the Temajuk village of West Kalimantan, Indonesia. The results were described in three major categories. They are the perceived benefits from the participants' point of view, tour guide training and English language learning, and participants' expectation. Overall, participants gave a positive response to the tour guide training. Future researchers are expected to seek more aspects regarding the tour guide training such as from the social-cultural aspect to enrich the literature and the extent to which the results of the training may benefit the community.

\section{ACKNOWLEDGMENT}

The authors would like to express their sincere gratitude to Daftar Isian Pelaksanaan Anggaran (DIPA) of State Polytechnic of Sambas for the support of finishing this research. The heartfelt thanks from the authors go to the village apparatus of Temajuk Village and the participants of this research as well as the students of State Polytechnic of Sambas who helped the research.

\section{REFERENCES}

Adam, L., \& Negara, S. D. (2015). Improving Human Capital through Better Education to Support Indonesia's Economic Development. Economics and Finance in Indonesia, 61 (2), 92106.

Bariyah, N., Fariastuti, Kurniasih, E. P. (2019). Pengembangan Desa Wisata Temajuk di Perbatasan IndonesiaMalaysia. Prosiding SATIESP 2019, 188-194

Berger, C., Kerner, N., \& Lee, J. (1999) Understanding Student Perceptions of Collaboration, Laboratory and Inquiry Use in Introductory Chemistry. Paper presented at the meeting of the National Association for Research in Science Teaching, Long Beach, CA.

Berger, C. The Participant Perception Indicator: A Compentency Based Elementary Teacher Preparation Program Model. University of Michigan carl.berger@umich.edu. Retrieved from https://www.slideserve.com/bette/th e-participant-perception-indicator-acompentency-based-elementaryteacher-preparation-program-model 
Deni, M. \& Winarni. S. (2017). Pengaruh Pramuwisata dan Promosi Terhadap Kunjungan Wisatawan Kota Palembang. Jurnal Manajemen dan Bisnis Sriwijaya, 15(1): 39-48. https://ejournal.unsri.ac.id/index.php /jmbs/article/view/5646

Fathin, C.A., Perdana, A. B., Kartikasari, A., \& Sulistyastuti, D. R. (2014). Indonesian Human Resources Readiness in term of Facing the ASEAN Economic Community. Jurnal Ilmu Sosial dan Ilmu Politik, 18(2), 81-89.

Isdarmanto, Dwiatmadja, C., Sunarto, H., \& Abdi, A. S. (2020). Enhancing innovation and sustainability regional tourism development in the era

industry 4.0. Journal of Business on Hospitality and Tourism, 6(1), 1-26. doi.org/10.22334/jbhost.v6i1.

Lonska, J., \& Boronenko, V. (2015). Rethinking Competitiveness and Human Development in Global Comparative Researches. Procedia Economics and Finance, 23, 10301036.

Miles, M. B., \& Huberman, A. M. (1994). Qualitative Data Analysis: An Expanded Sourcebook. Thousand Oaks, CA: Sage Publications.

Nurinsani1, A., Aini, W., \& Suardi. (2020). Analisis kualitas pelayanan pramuwisata dalam persepsi wisatawan di Museum La Galigo Kota Makassar. Jurnal Pariwisata, 7(2): 106-114.

Pertiwi, P. R., \& Sulistyawati, A. S. (2020). Factors of influence in choosing accommodation: A study with reference to mas village, an artistic heritage village in UbudBali, Journal of Business on Hospitality and Tourism 6(1), 2742. doi.org/10.22334/jbhost.v6i1.

Pirastyo, S. P., Putra, A. A., \& Kristiutami, Y. P. (2020). Upaya peningkatan kualitas pelayanan untuk meningkatkan kepuasan pelanggan di Alinea Catering. Journal of Tourism and Economic, 3(2), 97103.

Qiong, O. (2017). A Brief Introduction to Perception. Studies in Literature and Language, 15(4), 18-28.

Sugito, T., Sabiq, A., Faozanudin, A., \& Kuncoro, B. (2018). Aktor Penggiat Pemberdayaan Masyarakat di Perbatasan Pesisir Berbasis Ekowisata. Prosiding Seminar Nasional dan Call for Papers "Pengembangan Sumber Daya Perdesaan dan Kearifan Lokal

Weiler, B. and Ham, S.H. (2002). Tour guide training: A model for

sustainable capacity building in developing countries. Journal of Sustainable Tourism, 10 (1), 52-69.

Wisnawa, I. M. B., Wijayanti, A. A. R., Jokosaharjo, S. (2019). Tourists expectation and perception toward Sangeh tourism village. Journal of Sustainable Tourism, 5(2), 218-227. doi.org/10.22334/jbhost.v5i2.

Wijaya, N. S., Arcana, K. T. P., Sudarmawan, I. W. E. (2019). The role of tourism destination and human resources in sustainable tourism implementation in Indonesia. Journal of Sustainable Tourism, 5(2), 228237.doi.org/10.22334/jbhost.v5i2 